\title{
High Temperature Water Electrolysis Using Metal Supported Solid Oxide Electrolyser Cells (SOEC)
}

\author{
Günter Schiller ${ }^{1, a}$, Asif Ansar ${ }^{1, b}$ and Olaf Patz ${ }^{1, c}$ \\ ${ }^{1}$ German Aerospace Center (DLR), Institute of Technical Thermodynamics, \\ Pfaffenwaldring 38-40, D-70569 Stuttgart, Germany

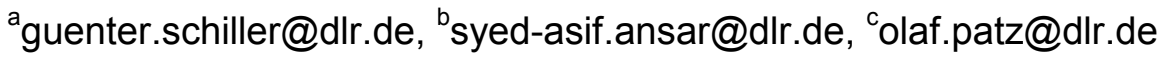

Keywords: High temperature steam electrolysis, metal supported cell, electrochemical performance, degradation behaviour, single cell, single repeating unit

\begin{abstract}
Metal supported cells as developed at DLR for use as solid oxide fuel cells by applying plasma deposition technologies were investigated in operation of high temperature steam electrolysis. The cells consisted of a porous ferritic steel support, a diffusion barrier layer, a Ni/YSZ fuel electrode, a YSZ electrolyte and a LSCF oxygen electrode. During fuel cell and electrolysis operation the cells were electrochemically characterised by means of i-V characteristics and electrochemical impedance spectroscopy measurements including a long-term test over 2000 hours. The results of electrochemical performance and long-term durability tests of both single cells and single repeating units (cell including metallic interconnect) are reported. During electrolysis operation at an operating temperature of $850{ }^{\circ} \mathrm{C}$ a cell voltage of $1.28 \mathrm{~V}$ was achieved at a current density of $-1.0 \mathrm{~A} \mathrm{~cm}^{-2}$; at $800{ }^{\circ} \mathrm{C}$ the cell voltage was $1.40 \mathrm{~V}$ at the same operating conditions. The impedance spectra revealed a significantly enhanced polarisation resistance during electrolysis operation compared to fuel cell operation which was mainly attributed to the hydrogen electrode. During a long-term test run of a single cell over 2000 hours a degradation rate of $3.2 \%$ per 1000 hours was observed for operation with steam content of $43 \%$ at $800{ }^{\circ} \mathrm{C}$ and a current density of $0.3 \mathrm{Acm}^{-2}$. Testing of a single repeating unit proved that a good contacting of cell and metallic interconnect is of major importance to achieve good performance. A test run over nearly 1000 hours showed a remarkably low degradation rate.
\end{abstract}

\section{Introduction}

Water electrolysis technologies are highly suited for the production of hydrogen based energy carriers to store electricity when renewable energy sources are used with increasing extent. In the low temperature range below $100{ }^{\circ} \mathrm{C}$ alkaline water electrolysers are commercially available [1]. Efficiencies of around $65 \%$ are reached with conventional alkaline water electrolysers whereas efficiencies exceeding $80 \%$ can be achieved by applying advanced technology with catalytically activated electrodes [2-4]. High temperature electrolysers which are operated in the temperature range of $700-1000{ }^{\circ} \mathrm{C}$ offer some additional advantages compared to the low temperature techniques. The higher operating temperature results in faster reaction kinetics thus enabling potentially high energy efficiency. From a thermodynamic point of view part of the energy demand for the endothermic water splitting reaction can be obtained from heat produced within the cell. The electric energy demand can be further significantly reduced if high temperature heat from renewable energy sources such as geothermal or solar thermal power, from nuclear power or waste heat from industrial processes is available. Furthermore, it is possible with high temperature electrolysis to not only split water steam but also carbon dioxide or a mixture of both to produce synthesis gas (syngas) or other energy carriers such as methane or methanol by subsequent catalytic conversion $[5,6]$. Already during the 1980's the development of solid oxide electrolyser cells (SOEC) for high temperature steam electrolysis was reported on the basis of tubular cells [7-11] but this development was then later stopped due to lower energy prices but also due to technical problems. In the past few years renewed interest on the SOEC technology appeared based on the progress 
achieved with planar SOFC technology [12-17]. The feasibility of planar SOFC cells and their limitations during electrolysis operation was investigated within the EU projects $\mathrm{Hi} 2 \mathrm{H} 2$ (Highly Efficient High Temperature Hydrogen Production by Water Electrolysis) [18] and RelHy [19]. At DLR Stuttgart metal supported cells have been fabricated by plasma spray technology and tested during fuel cell and electrolysis operation. This paper presents results of this cell type when investigated under varying operating conditions of steam electrolysis.

\section{Experimental details}

Metal supported cells (MSC) developed at DLR by applying plasma deposition technologies were used as solid oxide electrolyser cells (SOEC) for high temperature steam electrolysis. The cells consisted of a $1 \mathrm{~mm}$ thick porous metal sheet of ferritic steel (IT11) from Plansee, Austria, which serves as a substrate support. On top of it a diffusion barrier layer (DBL) was deposited either by plasma spraying or PVD process. Such a highly porous ceramic DBL on the basis of doped perovskite-type material has been developed at DLR to prevent mutual diffusion of $\mathrm{Cr}, \mathrm{Fe}$ and $\mathrm{Ni}$ species from substrate to hydrogen electrode and vice versa [20-22]. A Ni/YSZ hydrogen electrode (approx. $50 \mu \mathrm{m}$ thick), a YSZ electrolyte (approx. $40 \mu \mathrm{m}$ thick) and a LSCF oxygen electrode (approx. $30 \mu \mathrm{m}$ thick) were subsequently deposited by plasma spray technology where atmospheric conditions (APS) were applied for the porous electrodes and reduced operating pressure (VPS) for the dense electrolyte layer. The characteristics of the metal supported cells used are summarised in Table 1. Fig. 1 shows an optical micrograph of a metallographic cross section of this cell type. More details on cell fabrication are given in [23-25].

Table 1: Characteristics of used metal supported cells

\begin{tabular}{|l|l|l|l|l|}
\hline $\begin{array}{l}\text { Functional } \\
\text { Layer }\end{array}$ & Reference & Composition & $\begin{array}{l}\text { Thickness } \\
{[\mu \mathrm{m}]}\end{array}$ & $\begin{array}{l}\text { Fabrication } \\
\text { route }\end{array}$ \\
\hline Substrate & Plansee IT11 & $\begin{array}{l}\mathrm{Fe}-26 \mathrm{Cr} \\
(\mathrm{Mn}, \mathrm{Mo}, \mathrm{Ti}, \\
\left.\mathrm{Y}_{2} \mathrm{O}_{3}\right)\end{array}$ & $950-1050$ & PM \\
\hline Barrier Layer & H.C. Starck & $\begin{array}{l}\mathrm{La}_{0.6} \mathrm{Sr}_{0.2} \mathrm{Ca}_{0.2} \mathrm{CrO} \\
3\end{array}$ & $30-50$ & APS \\
\hline $\mathrm{H}_{2}$-electrode & Gen4 & $\begin{array}{l}\text { NiO-YSZ }(1: 1 \\
\text { mass })\end{array}$ & $40-60$ & APS \\
\hline Electrolyte & Gen3 & 9.5 mol\% YSZ & $40-60$ & VPS \\
\hline $\mathrm{O}_{2}$-electrode & Gen3 & $\begin{array}{l}\text { LSM/LSCF } \\
\text { LSM/LSCF }\end{array}$ & $\begin{array}{l}25-35 \\
15-40\end{array}$ & $\begin{array}{l}\text { APS } \\
\text { Screen printed }\end{array}$ \\
\hline
\end{tabular}




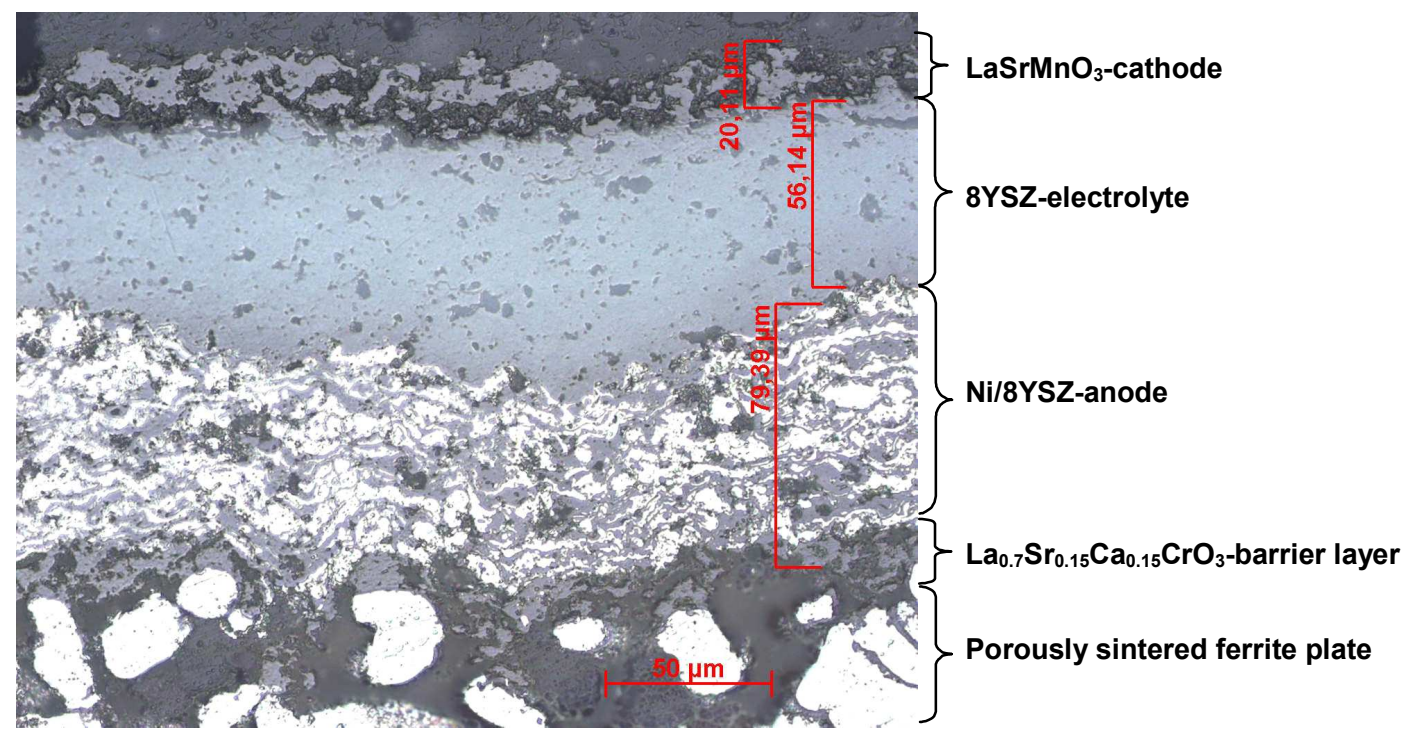

Fig. 1: Optical micrograph of a plasma sprayed SOFC cell

The cells with an active area of $12.5 \mathrm{~cm}^{2}$ were tested in a SOFC test rig that was modified for electrolysis operation. This modification comprised the implementation of a humidification system and capacitive dew point sensors for monitoring of humidity, a battery test system from BaSyTec, Germany, as a switchable source/load and automatic refilling of the humidification unit for longterm tests. The circular cells were mounted into a ceramic cell housing and placed between the ceramic flow fields of the hydrogen and oxygen electrode. The current collection from the cell was accomplished by two coarse platinum meshes; one below the substrate and one above the $\mathrm{O}_{2-}$ electrode. Pt wires were welded to the meshes to provide connection to the external circuit. The hydrogen/steam gas feed and exhaust feed was achieved by two concentric ceramic tubes with an inner tube for $\mathrm{H}_{2} / \mathrm{H}_{2} \mathrm{O}$ and air gas supply, respectively, and exhaust removal through the annular gap between the the two tubes. The sealing was done by gold rings and glass sealant paste. A cross sectional view of the set-up for cell characterisation is shown in Fig. 2.

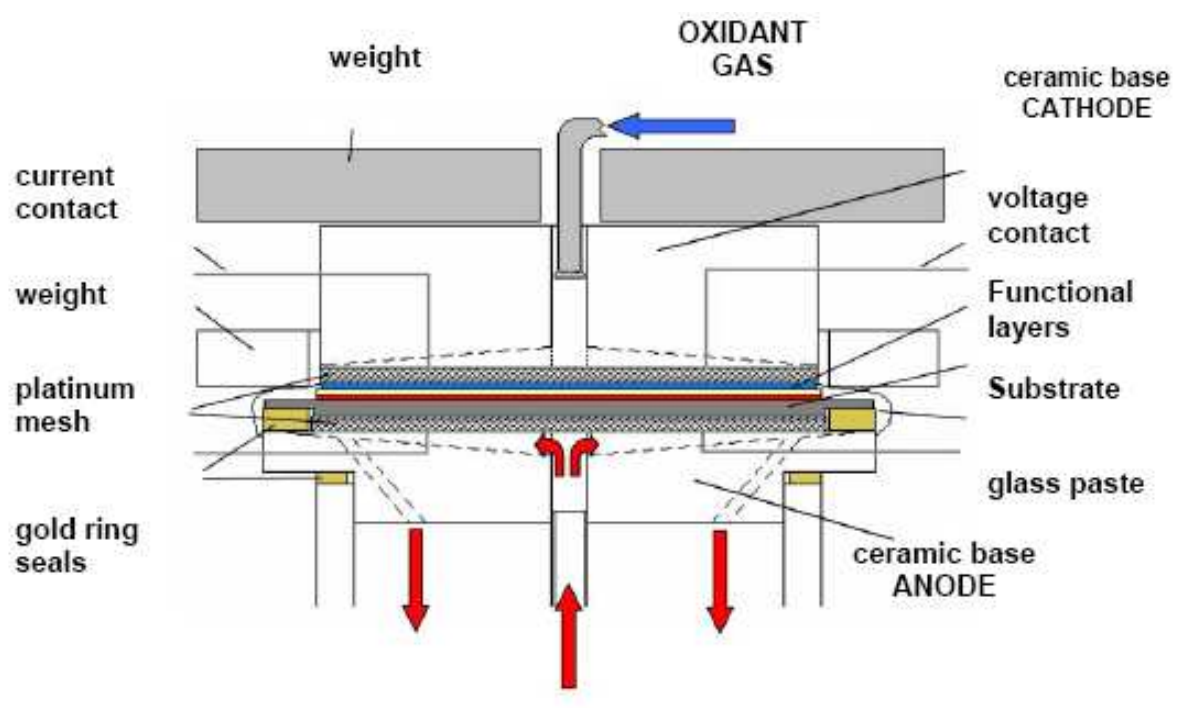

FUEL GAS

Fig. 2: Cross sectional view of the set-up for cell characterisation 
The cells were characterised in both fuel cell and electrolysis operation by $\mathrm{i}-\mathrm{V}$ characteristics and electrochemical impedance spectroscopy measurements using a Zahner IM6 system. Long-term electrolysis tests were performed by monitoring the cell voltage as a function of time. The operating temperature was $800{ }^{\circ} \mathrm{C}$ for long-term tests and varied between $750{ }^{\circ} \mathrm{C}$ and $850{ }^{\circ} \mathrm{C}$ during i-V characterisation. The gas flow rates were $40 \mathrm{ml} \mathrm{min}^{-1} \mathrm{~cm}^{-2} \mathrm{H}_{2}, 16 \mathrm{ml} \mathrm{min}^{-1} \mathrm{~cm}^{-2} \mathrm{H}_{2} \mathrm{O}(30 \%$ steam content) and $30 \mathrm{ml} \mathrm{min}^{-1} \mathrm{~cm}^{-2} \mathrm{H}_{2} \mathrm{O}$ (43\% steam content), respectively, and $160 \mathrm{ml} \mathrm{min}^{-1} \mathrm{~cm}^{-2}$ air during electrolysis operation.

For the test runs with single repeating units (SRU) a metallic interconnect plate was used consisting of CroFer22APU which contained channels for gas distribution and a plasma sprayed protective coating consisting of $\mathrm{MnCo}_{2} \mathrm{O}_{4}$. The circular cell and the coated interconnect plate used are depicted in Fig. 3. For contacting the cell with the interconnect a Pt grid in combination with a LSM contact paste was used that provided superior properties than using contact paste only. Probes for voltage measurement were placed at the interconnect and at the $\mathrm{O}_{2}$-electrode which made it possible to determine the contact resistance.

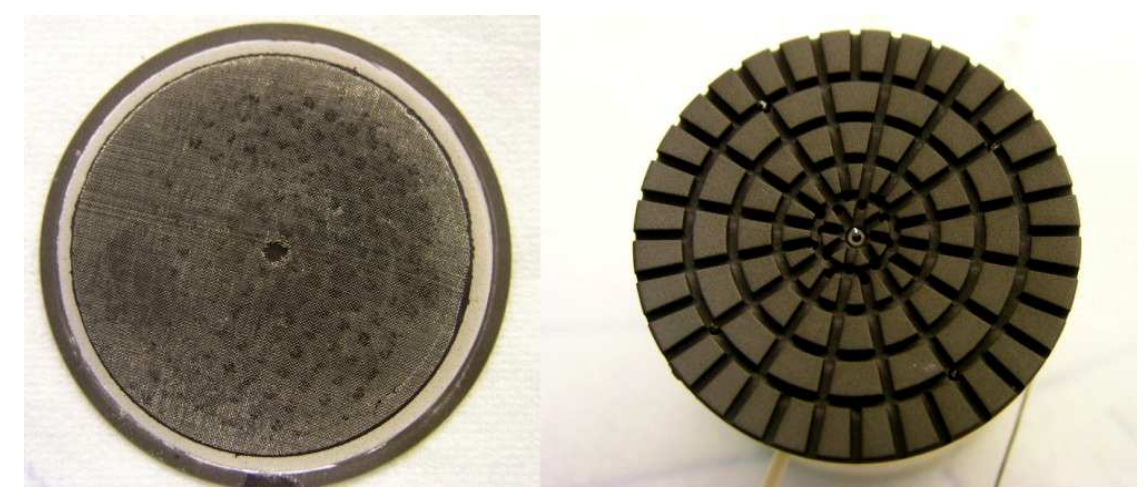

Fig. 3: Circular MSC cell and coated interconnect plate for testing of single repeating units

\section{Results and Discussion}

The cell performance of a single MSC cell in both fuel cell and electrolysis mode measured in the temperature range $750-850{ }^{\circ} \mathrm{C}$ is shown in Fig. $4.70 \%$ hydrogen and $30 \%$ steam was fed as inlet gas to the Ni/YSZ electrode. Positive current density refers to fuel cell operation and negative current density to electrolysis operation. At $800{ }^{\circ} \mathrm{C}$ the cell voltage at a current density of $-1.0 \mathrm{~A} \mathrm{~cm}^{-2}$ was about $1.4 \mathrm{~V}$ and at $850^{\circ} \mathrm{C}$ it was as low as $1.28 \mathrm{~V}$. At moderate current density such as $-0.3 \mathrm{~A} \mathrm{~cm}^{-2}$ as was applied as constant load during a long-term test run, the cell voltage was in the range of $1.07 \mathrm{~V}$ at $800{ }^{\circ} \mathrm{C}$ and $1.04 \mathrm{~V}$ at $850{ }^{\circ} \mathrm{C}$. Variation of the steam content from $43 \%$ to $92 \%$ that has been performed with another cell revealed that the cell performance increases with higher steam content. This effect is strongly pronounced at a temperature of $800{ }^{\circ} \mathrm{C}$ and below but at $850{ }^{\circ} \mathrm{C}$ a higher steam content did not affect the cell performance significantly.

A long-term test run over a period of more than 2000 hours with a constant current density of $-0.3 \mathrm{~A}$ $\mathrm{cm}^{-2}$ at $800{ }^{\circ} \mathrm{C}$ was carried out starting after 394 hours of operation. The steam content at the hydrogen electrode was kept constant at $43 \%$ for the whole test run. The cell voltage was monitored over time and $\mathrm{i}-\mathrm{V}$ and impedance characterisation was performed every 150 hours. The results of the durability test are summarised in Fig. 5 . The cell voltage increased by about $26 \mathrm{mV}$ during the first 1000 hours of long term operation which corresponds to a degradation of $2.1 \% 1000 \mathrm{~h}^{-1}$. During the next 1000 hours $(1400 \mathrm{~h}$ to $2400 \mathrm{~h})$ an increase in cell voltage of $46 \mathrm{mV}$, respectively 


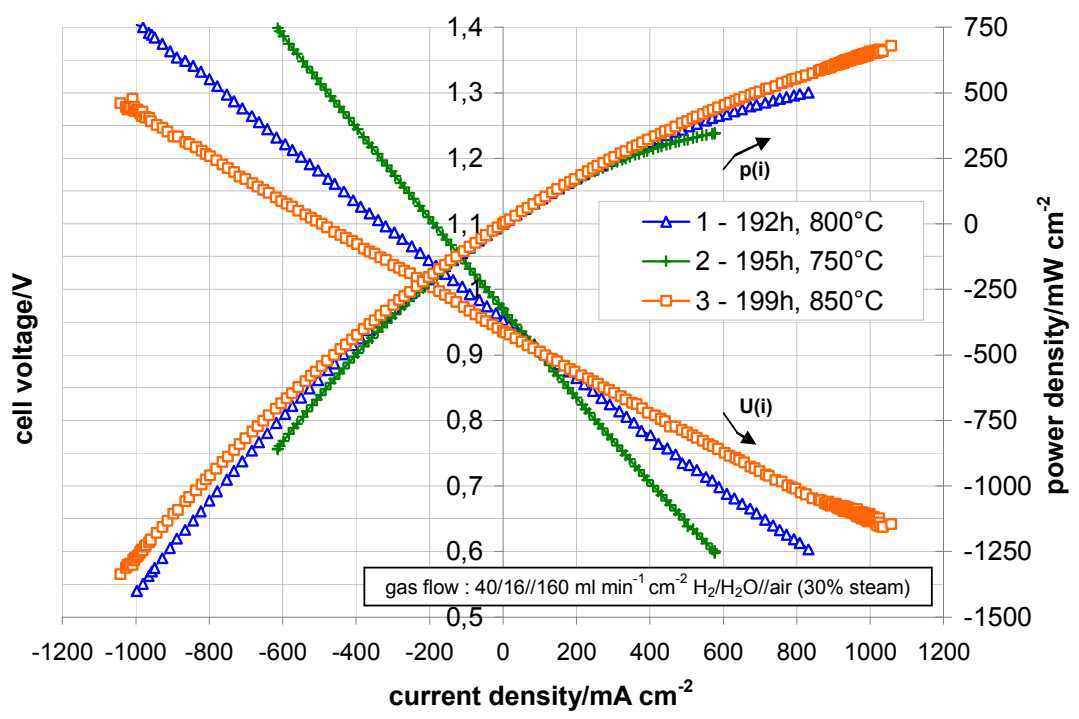

Fig. 4: I-V and i-p characteristics of a MSC cell during both fuel cell and electrolysis operation in the temperature range $750-850{ }^{\circ} \mathrm{C}$ and a gas flow of $40 / 16 / 160 \mathrm{ml} \mathrm{min}^{-1} \mathrm{~cm}^{-2} \mathrm{H}_{2} / \mathrm{H}_{2} \mathrm{O} /$ air $(30 \%$ steam $)$

$3.9 \% 1000 \mathrm{~h}^{-1}$, was observed. This results in an increase of $72 \mathrm{mV}$ for the whole period of 2027 hours corresponding to a degradation rate of $3.2 \% 1000 \mathrm{~h}^{-1}$. These different values might be caused by different degradation mechanisms, e.g. changes in the microstructure of the electrodes, the electrolyte or the substrate.

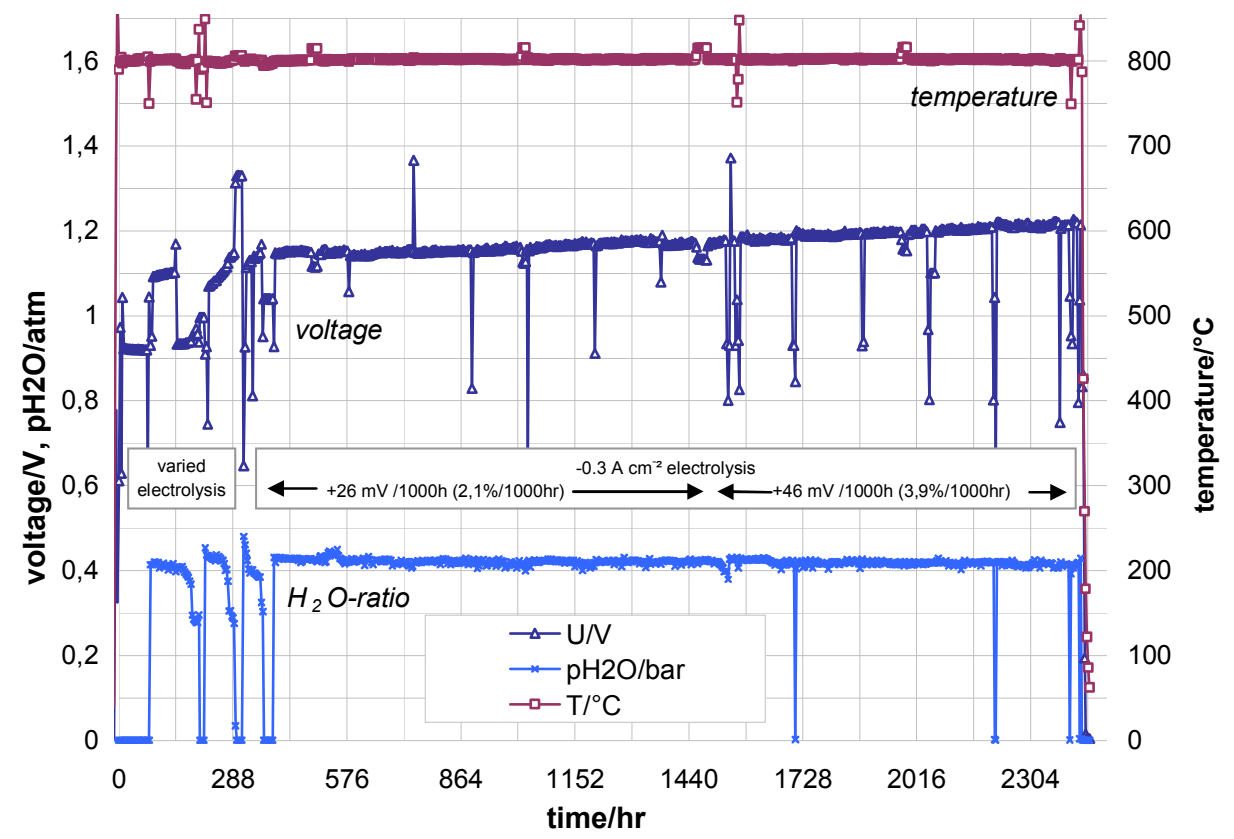

Fig. 5: Long-term test run of a MSC cell with a continuous load of $-0.3 \mathrm{~A} \mathrm{~cm}^{-2}$ in electrolysis mode over more than 2000 hours of operation; temperature (top), voltage (middle) and steam partial pressure (bottom) were monitored. 
In order to investigate these different degradation mechanisms of the cell in more detail, impedance spectroscopy at different operating times was performed. From the corresponding Nyquist and Bode plots of the cell at OCV between $193 \mathrm{~h}$ and $1540 \mathrm{~h}$ it can be seen that during this time the ohmic resistance in the high frequency range has increased from about $260 \mathrm{~m} \Omega \mathrm{cm}^{2}$ at $193 \mathrm{~h}$ to $320 \mathrm{~m} \Omega$ $\mathrm{cm}^{2}$ at $1540 \mathrm{~h}$. This increase of $60 \mathrm{~m} \Omega \mathrm{cm}^{2}$ can be explained by oxidation processes of the porous metallic IT substrate which were observed in the microstructure of the substrate after the $2000 \mathrm{~h}$ of operation (see Fig. 6). Moreover, a significant increase of the overall impedance from $450 \mathrm{~m} \Omega \mathrm{cm}^{2}$ to $670 \mathrm{~m} \Omega \mathrm{cm}^{2}$ can be observed. This corresponds to an increase of the overall polarisation impedance from $190 \mathrm{~m} \Omega \mathrm{cm}^{2}$ after $193 \mathrm{~h}$ to $320 \mathrm{~m} \Omega \mathrm{cm}^{2}$ after $393 \mathrm{~h}$ and $350 \mathrm{~m} \Omega \mathrm{cm}^{2}$ after $1540 \mathrm{~h}$. The strongest change can be observed during the first $400 \mathrm{~h}$ when $\mathrm{i}-\mathrm{V}$ characterisation measurements under temperature variation were performed, whereas after this period only relatively small changes were observed. The changes can be attributed to the increase of the polarisation resistances of the fuel and the $\mathrm{O}_{2}$-electrode. Due to the strong overlapping of these two processes, it is difficult to clearly separate the contribution of the hydrogen and oxygen electrode. However, the post-analysis of the microstructure of the cell after operation in Fig. 6 has shown coarsening especially of the $\mathrm{Ni}$ particles of the hydrogen electrode. This may lead to a decrease of the electrochemical activity of the anode through the reduction of the triple phase boundary.

The impedance spectra of the cell monitored at a current density of $0.4 \mathrm{~A} \mathrm{~cm}^{-2}$ in fuel cell and in electrolysis mode as a function of operating time show, according to the theory, that the ohmic resistances in fuel cell and electrolysis mode are identical. The values are in the range of $260 \mathrm{~m} \Omega$ $\mathrm{cm}^{2}$ to $320 \mathrm{~m} \Omega \mathrm{cm}^{2}$. Similar to the spectra at OCV, in both cases an increase of the ohmic resistance of about $60 \mathrm{~m} \Omega \mathrm{cm}^{2}$ during operation of $1540 \mathrm{~h}$ can be observed. This increase can be explained with the above described formation of oxide layers in the porous metallic substrate. The overall impedances in the fuel cell mode are in the range of $170 \mathrm{~m} \Omega \mathrm{cm}^{2}$ to $220 \mathrm{~m} \Omega \mathrm{cm}^{2}$ and are lower in comparison to the electrolysis mode. In this case the values are $220 \mathrm{~m} \Omega \mathrm{cm}^{2}$ to $660 \mathrm{~m} \Omega \mathrm{cm}^{2}$. These differences can be explained by the higher polarisation resistances of the electrodes in the electrolysis mode. In this case, especially the high water content of the fuel electrode leads to a higher activation polarisation. Furthermore, the results of the impedance spectra are in good agreement with the slope of the current-voltage curves which represent the area specific resistances (ASR) of the cell. At a current density of $0.4 \mathrm{~A} \mathrm{~cm}^{-2}$ the slopes of the electrolysis curves are much higher in comparison to the slopes of the fuel cell curves. The increase of the overall polarisation impedances are therefore in the range of $440 \mathrm{~m} \Omega \mathrm{cm}^{2}$ for the electrolysis mode and $50 \mathrm{~m} \Omega \mathrm{cm}^{2}$ for the fuel cell mode. Hence, the degradation in polarisation resistance is much higher for electrolysis mode than for fuel cell mode. In both cases similar to the spectra at $\mathrm{OCV}$, the strongest increase in polarisation resistances can be observed during the first $400 \mathrm{~h}$.

A SEM micrograph of the cell after $2425 \mathrm{~h}$ of operation is shown in Fig. 6. Major changes in the different functional layers or cracks could not be observed. But oxide scales on the rim of the substrate particles indicate a certain oxidation of the ferritic steel substrate during operation. EDX analysis (EDX mapping and EDX line-scan) of a cross section of the cell proved the efficiency of the PVD diffusion barrier layer. Only very small amounts of $\mathrm{Fe}$ and $\mathrm{Cr}$ species could be detected in the hydrogen electrode and no $\mathrm{Ni}$ species were found in the substrate indicating that species migration has been efficiently prevented by the diffusion barrier layer [26]. 

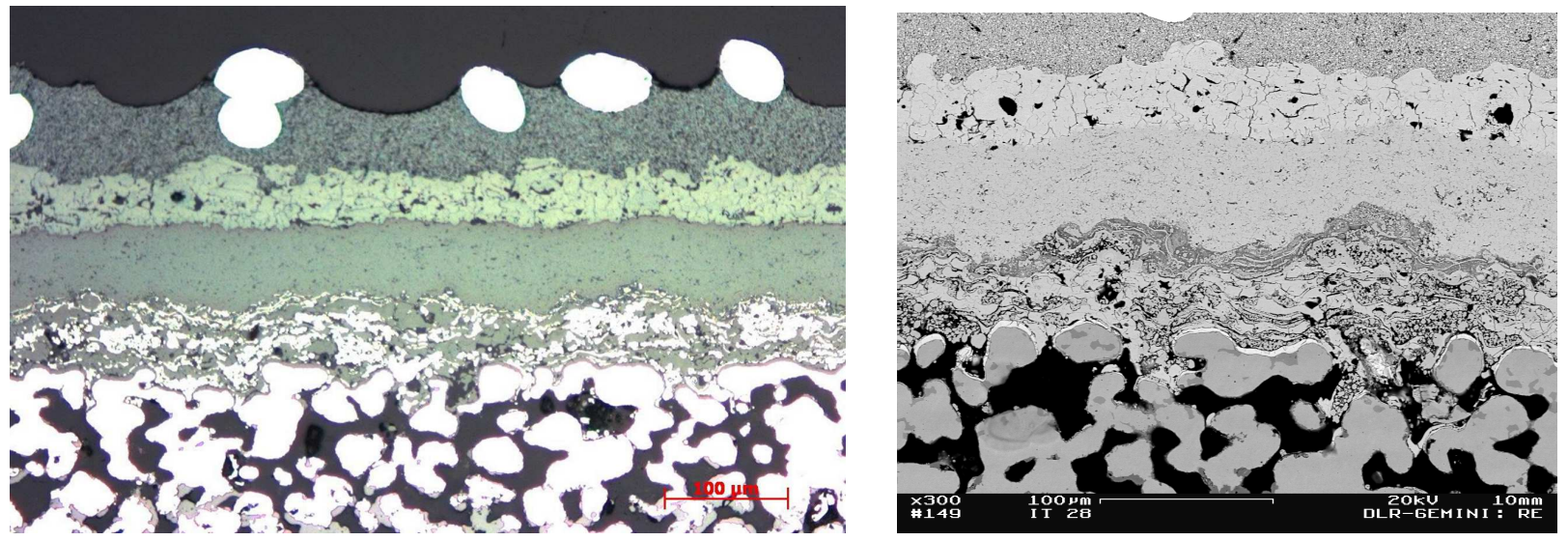

Fig. 6: Micrographs of the cross section of the plasma sprayed cell after $2425 \mathrm{~h}$ of operation (left: optical microscope / right: scanning electron microscope)

In addition to the single cell tests, test runs with single repeating units (SRU) of a plasma sprayed cell and a metallic interconnect were performed. The cells were of the same type as described before including a diffusion barrier layer. Fig. 7 showing the performance of an SRU in both fuel cell and electrolysis mode for different operating times $(83 \mathrm{~h}$ and $290 \mathrm{~h})$ reveals an improvement of performance with time reaching a cell voltage of $1.3 \mathrm{~V}$ at $1 \mathrm{~A} \mathrm{~cm}^{-2}$ and $800{ }^{\circ} \mathrm{C}$ after nearly 300 hours of operation when measured at the $\mathrm{O}_{2}$-electrode. Voltage measurement at the interconnect showed a higher voltage of approximately $100 \mathrm{mV}$ due to the contact resistance. Measurements with SRUs contacted without the Pt grid showed a much higher voltage indicating that the contacting area without the grid is much lower resulting in an enhanced contact resistance. To achieve good performance in a stack, contacting of cell and interconnect is a critical and important issue needing much attention to be paid.

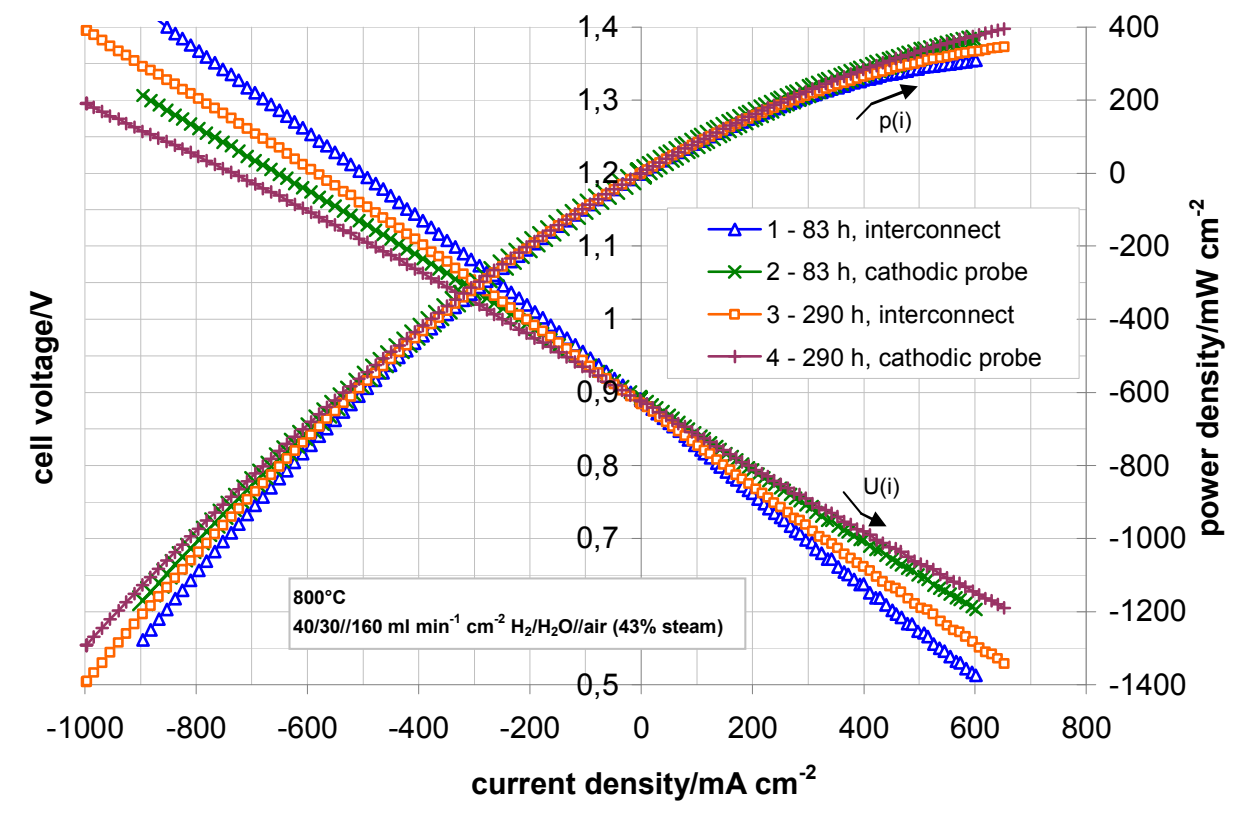

Fig. 7: I-V and i-p characteristics of a single repeating unit (MSC cell with coated interconnect) during both fuel cell and electrolysis operation at $800{ }^{\circ} \mathrm{C}$ after different operating times $(83 \mathrm{~h}$ and $290 \mathrm{~h}$ ). Probes for voltage measurement are placed at the $\mathrm{O}_{2}$-electrode (symbols $\mathrm{x}$ and $\rightarrow$ ) and at the interconnect (symbols $\Delta$ and $\square$ ). Gas flow: 40/30/160 ml min $\mathrm{cm}^{-2}$ $\mathrm{H}_{2} / \mathrm{H}_{2} \mathrm{O} /$ air $(43 \%$ steam) 
The behaviour during long-term testing of the SRU is summarised in Fig. 8. At constant electrolysis operation with $0.3 \mathrm{~A} \mathrm{~cm}^{-2}$ over about $940 \mathrm{~h}$ practically no degradation was observed. In the period between $830 \mathrm{~h}$ and $960 \mathrm{~h}$ of operation the monitored cell voltage showed unusual behaviour with a decrease and a following increase which was probably caused by the failure of another SRU that occurred in that period in the same test rig.

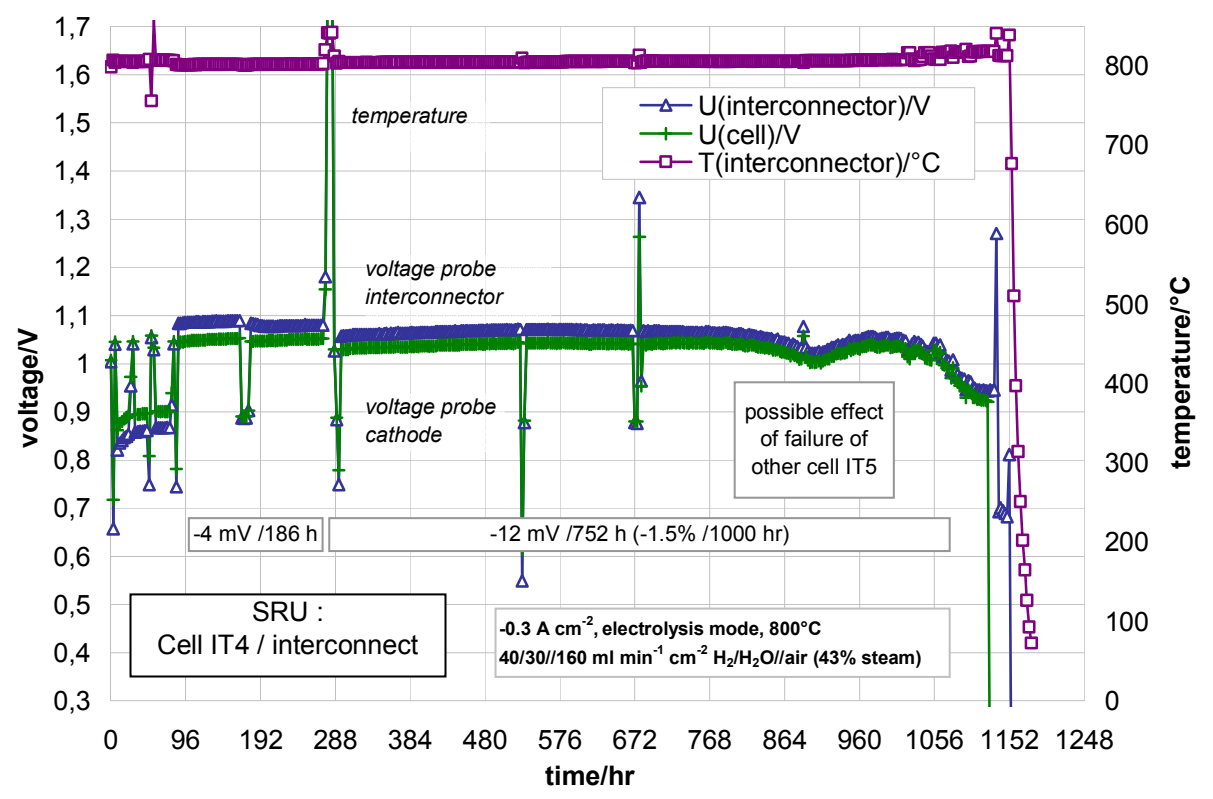

Fig. 8: Long-term test run of a single repeating unit (MSC cell with coated interconnect) with a continuous load of $-0.3 \mathrm{~A} \mathrm{~cm}^{-2}$ in electrolysis mode over 940 hours of operation; temperature (top) and voltage at different positions (at interconnect and at $\mathrm{O}_{2}$-electrode) were monitored. Gas flow: 40/30/160 $\mathrm{ml} \mathrm{min}^{-1} \mathrm{~cm}^{-2} \mathrm{H}_{2} / \mathrm{H}_{2} \mathrm{O} /$ air $(43 \%$ steam).

\section{Summary}

Metal supported cells according to the SOFC concept of DLR were investigated for use as solid oxide electrolyser cells (SOEC) for high temperature steam electrolysis. Cells consisting of a porous ferritic steel support, a diffusion barrier layer, a Ni/YSZ hydrogen electrode, a YSZ electrolyte and a LSCF oxygen electrode were electrochemically characterised by means of i-V characteristics and electrochemical impedance spectroscopy measurements including a long-term test over 2000 hours. The cell voltage during electrolysis operation at a current density of $-1.0 \mathrm{~A} \mathrm{~cm}^{-2}$ was $1.28 \mathrm{~V}$ at an operating temperature of $850^{\circ} \mathrm{C}$ and $1.4 \mathrm{~V}$ at $800{ }^{\circ} \mathrm{C}$. A long-term test run over 2000 hours with a steam content of $43 \%$ at $800{ }^{\circ} \mathrm{C}$ and a current density of $-0.3 \mathrm{~A} \mathrm{~cm}^{-2}$ showed a degradation rate of $3.2 \%$ per 1000 hours. The impedance spectra revealed a significantly enhanced polarisation resistance during electrolysis operation compared to fuel cell operation which was mainly attributed to the hydrogen electrode. A test run of a single repeating unit over nearly 1000 hours showed a remarkably low degradation rate. However, further development work is needed to further improve electrolysis performance, and, in particular, to further decrease the degradation rate at long-term operation with high current density. 


\section{References}

[1] J. Divisek, H. Wendt (1990), in: Electrochemical Hydrogen Technologies, edited by H. Wendt, Elsevier, Amsterdam (1990)

[2] W. Kreuter, H. Hofmann, in: Hydrogen Energy Progress XI, edited by T.N. Veziroglu, C.J. Winter, J.P. Baselt, G. Kreysa, International Association for Hydrogen Energy (1996)

[3] H. Janssen, B. Emonts, H.G. Groehn, H. Mai, R. Reichel, D. Stolten: HYPOTHESIS IV Vol. 1 (2001), p. 172

[4] G. Schiller, R. Henne, P. Mohr, V. Peinecke: Int. J. Hydrogen Energy Vol. 23(9) (1998), p.761

[5] M. Mogensen, C. Bagger: Proc. 1998 Fuel Cell Seminar Palm Springs, CA, USA (1998), p.96

[6] M. Mogensen, S.H. Jensen, A. Hauch, I. Chorkendorff, T. Jacobsen: Proc. $7^{\text {th }}$ European SOFC Forum Lucerne (2006), PO301

[7] W. Dönitz, R. Schmidberger, E. Steinheil, R. Streicher: Int. J. Hydrogen Energy Vol. 5(1) (1980), p.55

[8] W. Dönitz, E. Erdle: Int. J. Hydrogen Energy Vol. 10(5) (1985), p.291

[9] W. Dönitz, E. Erdle, in: Electrochemical Hydrogen Energy Technologies, Electrochemical Production and Combustion of Hydrogen, edited by H. Wendt, Elsevier, Amsterdam (1990)

[10] E. Erdle, W. Dönitz, R. Schramm, A. Koch: Int. J. Hydrogen Energy Vol. 17(10) (1992), p.817

[11] A.O. Isenberg: Solid State Ionics Vol. 3-4 (1981), p.431

[12] J. Hartvigsen, S. Elangovan, J.E. O’Brien, C.M. Stoots, J.S. Herring, P. Lessing: Proc. $6^{\text {th }}$ European SOFC Forum Lucerne (2004), p.378

[13] J.E. O'Brien, C.M. Stoots, J.S. Herring, J. Hartvigsen: J. Fuel Cell Science and Technol. Vol. 3(2) (2006), p.213

[14] H.S. Hong, U. Chae, S.T. Choo, K.S. Lee: J. of Power Sources Vol. 149 (2005), p.84

[15] W.S. Wang, Y.Y. Huang, S.W. Jung, J.M. Vohs, R.J. Gorte: J. of the Electrochem. Soc. Vol. 153(11) (2006), p. A2066

[16] H. Uchida, N.N. Osada, M. Watanabe: Solid-State Letters Vol. 7(12) (2004), p. A500

[17] N.N. Osada, H.Uchida, M. Watanabe: J. of the Electrochem. Soc. Vol. 153(5) (2006), p. A816

[18] A. Brisse A, M. Mogensen, G. Schiller, U. Vogt, M. Zahid: Proc. $17^{\text {th }}$ World Hydrogen Energy Conference (WHEC2008) Brisbane, Australia (2008)

[19] Information on http://www.relhy.eu

[20] R.H. Henne, T. Franco, R. Ruckdäschel: J. Therm. Spray Technol. Vol. 15(4) (2006), p. 695

[21] T. Franco, Z. HoshiarDin, P. Szabo, M. Lang, G. Schiller: Journal of Fuel Cell Science and Technology Vol. 4(4) (2007), p. 406

[22] T. Franco, K. Schibinger, Z. Ilhan, G. Schiller, A. Venskutonis: Proc. 10th International Symposium on Solid Oxide Fuel Cells (SOFC-X) Nara, Japan (2007), electronic paper

[23] A.A. Syed, Z. Ilhan, J. Arnold, G. Schiller, H. Weckmann: J. Therm. Spray Technol. Vol. 15(4) (2006), p. 617

[24] S.A. Ansar, Z. Ilhan, W. Richter: High Temp. Mater. Process. Vol. 11(1) (2007), p. 83

[25] S.A. Ansar, Z. Ilhan: MRS Spring Meeting San Francisco USA (2007), electronic paper

[26] D. Wiedenmann, U.F. Vogt, C. Soltmann, O. Patz, G. Schiller, B. Grobety: Fuel Cells Vol. 9(6) (2009), p. 861 